\title{
DETERMINING THE STATUS OF ANXIETY AND DEPRESSION IN WOMEN DURING PREGNANCY AND IN THE POSTPARTUM PERIOD

\author{
Rukiye Türk ${ }^{1}$, Reyhan Erkaya ${ }^{2}$
}

\begin{abstract}
:
Problem Statement: The anxiety and depression experienced during pregnancy and in the postpartum period is of considerable importance in terms of the health of the mother and her infant.

Purpose of the Study: The aim of this study was to determine the status of anxiety and depression during pregnancy and in the postpartum period.

Methods: The research sample consisted of 100 primiparae and 100 multiparae who had consented to participate in the study. Data was collected with a questionnaire, the State and Trait Anxiety Inventory (STAI), the Beck Anxiety Inventory (BAI), and the Edinburgh Postpartum Depression Scale (EPDS).

Findings and Results: It was found that during pregnancy and in the postpartum period, primiparae experienced a higher level of state and trait anxiety compared to multiparae and that the rate of depression was higher in multiparae compared to primiparae.

Conclusions and Recommendations: It was determined that primiparae experienced more anxiety than multiparae $(p<0.05)$ during pregnancy and in the postpartum period and that multiparae experienced depression at a higher rate. Therefore, our recommendation is that healthcare personnel provide women with a regular program of education and consulting services to meet their needs during pregnancy and in the postpartum period.
\end{abstract}

UDC Classification: 618; DOI: http://dx.doi.org/10.12955/cbup.v6.1280

Keywords: Primipara, Multipara, Anxiety, Depression

\section{Introduction}

Pregnancy, childbirth and the postpartum period, although being natural physiological processes, are times that also bring emotional reactions into play such as worry, anxiety and stress due to the biological and psychosocial changes experienced through the impact of hormones (Akdeniz \& Gönül, 2004). While some women readily adapt to these changes, others live through different degrees of psychological issues (Beck, 2001).

Besides emotional ups and downs, anxiety during pregnancy and postpartum depression has been observed in recent years to be at levels that cannot be ignored (Faisal-Cury \& Rossi Menezes, 2007; Virit et al., 2008). A look into the studies that have been conducted in Turkey on depression during pregnancy show us that depression rates are reported as 22.6\% (Erkaya et al., 2012), 27.3\% (Karaçam \& Ançel 2007) and 27.5\% (Gölbaş1 et al., 2010). While the rates around the world have been found to be 19.6\% (Faisal-Cury \& Rossi Menezes, 2007), 20\% (Marcus et al., 2003), 25\% (Da Costa et al., 2000) and 30\% (Kurki et al., 2000).

When we examine studies on anxiety and depression experienced together during pregnancy, it can be seen that in one study that has looked into psychological states over the trimesters, it is reported that the anxiety and depression observed in the first and third trimesters is at a higher rate than in the second trimester (Kuğu, \& Akyüz, 2001). Similarly, in another study, it is asserted that anxiety (54\%) and depression $(37.1 \%)$ in the first and third trimesters of pregnancy is experienced more severely and intensely than in the second trimester (Lee et al., 2007).

Issues such as anxiety and depression experienced during pregnancy are of considerable importance in terms of the health of the mother and her infant. Studies examining the negative impact of anxiety and depression during pregnancy on the newborn state that these conditions affect placental perfusion and increase the risk of preterm labor (Orr et al., 2002; Hoffman \& Hatch, 2000; Hobel, 1999). Anxiety and depression experienced during pregnancy inevitably reflect upon the postpartum period as well. In a study exploring the outcome of this, it has been pointed out that more than $50 \%$ of women experience anxiety and depression over the course of pregnancy and that their depression extends into the postpartum period (Bloch et al., 2003).

There are numerous studies in Turkey and in the international literature about postpartum depression. Studies from around the world reveal that postpartum depression rates vary between $10.0 \%-21.7 \%$

\footnotetext{
${ }^{1}$ Kafkas University, Kars, Turkey, rahsantur@gmail.com

${ }^{2}$ Karadeniz Technical University, Trabzon, Turkey, reyhanozturk30@hotmail.com
} 
(Bloch et al., 2006; Robertson et al., 2004; Woolhouse et al., 2014; Stewart et al., 2008). In the Turkish literature, the postpartum depression rate has been reported to be in the range of $15.0 \%-51.3 \%$ Durukan et al., 2011; Sünter et al., 2006; İnand1 et al., 2005; Nur et al., 2004; Y1ldırım et al.,2011). It is likely that the differences between the rates in the various studies stem from the differences in social structure in the regions where the studies have been conducted.

Pregnancy and the postpartum period are times in a woman's life where social dynamics have changed, and women must adapt to their new position in the family. Bonds of love and trust between a mother and child are essentially formed in this time period, which also represents a time of crisis during which mothers and fathers need to adjust to their roles as parents. This is when identifying the anxiety, worry, depression and other issues that arise during pregnancy and the postpartum period is vital and an intervention is needed if a healthy and successful period of adjustment is to be expected (Karaçam \& Ançel, 2007; Faisal-Cury, \& Rossi Menezes, 2007; Yıldırım et al., 2011). It was for this reason that the aim of this study was to determine the status of women's anxiety and depression during pregnancy and in the postpartum period so that a contribution may be made to the literature.

\section{Materials and methods}

Aim and Form of the Study

The research was conducted as cross-sectional study to determine the status of anxiety and depression during pregnancy and in the postpartum period.

Study Population and Sample

The study sample consisted of 100 consenting pregnant primiparae and 100 pregnant multiparae who presented to the Maternity Polyclinic of Trabzon Kanuni Training and Research Hospital over the period June 1 - December 30, 2016.

Data collection instruments and their characteristics: The data was collected in two stages: the Pregnancy Period and the Postpartum Period. The tools used in the pregnancy period were a Questionnaire of 24 items on information about the women's sociodemographic and obstetric characteristics, the State and Trait Anxiety Inventory (STAI), and the Beck Anxiety Inventory (BAI). In the second month postpartum, the women were administered the Edinburgh Postpartum Depression Scale (EPDS) and the State and Trait Anxiety Inventory (STAI).

State and Trait Anxiety Inventory (STAI): Developed by Spielberger et al., this inventory was adapted to the Turkish culture by Öner and Le Compte (1983). Its validity, reliability and norm studies having been completed, the inventory comprises two subscales pertaining to state anxiety and trait anxiety, each containing 20 questions. The state anxiety scale determines how an individual feels at a particular moment and under particular conditions while the trait anxiety scale measures how the person feels independent of surrounding circumstances or conditions. Emotions or behavior in the inventory items of the state anxiety scale are expressed in terms of the degree to which these are felt, such that an appropriate response is chosen from the following: (1) not at all, (2) a little, (3) very much, (4) totally. There are 10 items in the inventory that are rated in reverse. These items are statements 1, 2, 5, 8, 10, $11,15,16,19$ and 20 . The state anxiety score is calculated by adding 50 points to the difference between the total weighted scores of the direct and reverse statements. The scores obtained on the state anxiety scale theoretically vary between $20-80$ points. In the assessment of the inventory, it is accepted that scores below 36 represent a lack of anxiety, scores between 37-42 mean slight anxiety, and scores of 42 and over represent a high level of anxiety (Öner \& Le Compte, 1983).

Beck Anxiety Inventory (BAI): This instrument was created in 1939 by Aaron Beck et al. and the Turkish adaptation was completed by Ulusoy et al. The inventory is a self-reporting construct that aims to measure the risk of anxiety disorder and its severity. The Beck Anxiety Inventory (BAI) has 21 questions that were developed in order to identify the severity of anxiety. Each item is rated on a 4point Likert-type scale with responses that range from 0 (Not at all) to 3 (severe, I have trouble coping). Overall scores are calculated and the total score ranges between $0-63$. The inventory may be administered to adults and adolescents over the age of 15 . Scores of 0-9 indicate no depression, 10-16 slight depression, 17-24 average depression, and a score of 25 or over points to severe depression. The BAI was developed by Beck et al. (1988) and its adaptation into Turkish was carried out by Ulusoy et al. (1993). The test-retest correlation for the BAI is 0.75 and its internal consistency coefficient has been calculated as 0.92 (Beck et al., 1988; Ulusoy et al., 1998). 
Edinburgh Postpartum Depression Scale (EPDS): The EPDS is a self-reporting Likert-type of scale comprising 10 items rated on the basis of 4 points. The responses to be chosen from 4 multiple choices are scored as 0-3; the lowest score to be derived from the scale is 0 while the highest is 30 . In the evaluation, while items 1,2 and 4 are rated as $0,1,2,3$, items $3,5,6,7,8,9$ and 10 are reversely rated as $3,2,1,0$. Engindeniz adapted the EPDS into the Turkish language. In the validity and reliability study conducted by Engindeniz, the scale's internal consistency coefficient was found to be 0.79 , splithalf reliability was 0.80 , sensitivity at the cut-off point of $12 / 13$ was 0.84 , specificity was 0.88 , the positive predictive value was 0.69 and the negative predictive value was found to be 0.94 . The cut-off point on the EPDS was calculated as 13 and women with a scale score of 13 or more were considered to be in the risk group. Participants with an EPDS score of $\leq 12$ were considered not at risk of PPD and those with scores of $\geq 13$ were regarded as being in the risk group (Engindeniz et al., 1997; Karaçam \& Kitiş, 2007).

Ethical Considerations of the Study:

The approval of the Trabzon Kanuni Training and Research Hospital Ethics Committee and the required permissions were obtained prior to the start of the study. All of the women approached were informed about the purpose of the research, after which the women consenting to participate were recruited into the study.

Statistical Analysis of the Data

The data was analyzed with the SPSS for Windows 22 package program. Numbers, percentages, means and standard deviation were used in the analysis of the data. In the assessment of the descriptive characteristics of dependent variables, the Kolmogorov-Smirnov and Shapiro-Wilk tests were employed to determine whether the data exhibited normal distribution. A t-test was used in the comparison of the quantitative continuous variables between two independent groups. The results were found to be in the $95 \%$ confidence interval; significance was considered to be $p<0.05$.

\section{Results}

Among the pregnant primiparae, 56\% were of the age of 25 and below, $41 \%$ were high school graduates, $79 \%$ were unemployed, the spouses of $42 \%$ were university graduates, the spouses of $33 \%$ were workers, $98 \%$ had social security, $93 \%$ perceived their monthly income as average, $82 \%$ were from a nuclear family, 93\% lived in an apartment and 95\% had been married 1-5 years. Among the pregnant multiparae, $38 \%$ were of the ages $26-30,31 \%$ were elementary school graduates, $82 \%$ were unemployed, $36 \%$ were high school graduates, the spouses of $50 \%$ were self-employed, $97 \%$ had social security, $81 \%$ perceived their monthly income as average, $80 \%$ were from a nuclear family and $78 \%$ lived in an apartment.

It was found that the state anxiety scores of the pregnant primiparae $(x=47.090)$ were higher that the state anxiety scores of the multiparae $(\mathrm{x}=41.270)$ and that the difference between the group mean scores was significant $(\mathrm{t}=7.087 ; \mathrm{p}=0<0.05)$. It was seen that the trait anxiety scores of the pregnant primiparae $(x=48.810)$ were higher that the trait anxiety scores of the multiparae $(x=44.890)$ and that the difference between the group mean scores was significant $(t=3.605 ; \mathrm{p}=0<0.05)$. The depression scores $(x=9.070)$ of the pregnant primiparae were lower than the scores of the multiparae $(x=11.830)$ and it was observed that the difference between the group mean scores was significant $(t=3.094$; $\mathrm{p}=0.002<0.05)$.

The depression scores $(\mathrm{x}=4.520)$ of the postpartum primiparae were lower than the scores of the multiparae $(x=5.950)$ but it was observed that the difference between the group mean scores was not significant $(\mathrm{t}=1.848 ; \mathrm{p}=>0.05)$. It was found that the state anxiety scores of the postpartum primiparae $(\mathrm{x}=45.160)$ were higher that the state anxiety scores of the multiparae $(\mathrm{x}=40.490)$ and that the difference between the group mean scores was significant $(t=6.136 ; \mathrm{p}=0<0.05)$. It was seen that the trait anxiety scores of the postpartum primiparae $(\mathrm{x}=45.560)$ were higher that the trait anxiety scores of the multiparae $(\mathrm{x}=41.630)$ and that the difference between the group mean scores was significant $(\mathrm{t}=4.585 ; \mathrm{p}=0<0.05)$. 


\begin{tabular}{|c|c|c|c|c|c|}
\hline \multirow{3}{*}{\multicolumn{2}{|c|}{ Characteristics }} & \multicolumn{4}{|c|}{ Parity (Number of childbirths) } \\
\hline & & \multicolumn{2}{|c|}{ Primiparae } & \multicolumn{2}{|c|}{ Multiparae } \\
\hline & & $\mathbf{n}$ & $\%$ & $\mathbf{n}$ & $\%$ \\
\hline \multirow{4}{*}{ Age } & Age 25 and less & 56 & $56.0 \%$ & 16 & $16.0 \%$ \\
\hline & Ages 26-30 & 33 & $33.0 \%$ & 38 & $38.0 \%$ \\
\hline & Ages 31-35 & 9 & $9.0 \%$ & 27 & $27.0 \%$ \\
\hline & Ages over 35 & 2 & $2.0 \%$ & 19 & $19.0 \%$ \\
\hline \multirow{4}{*}{ Education } & Elementary School & 4 & $4.0 \%$ & 31 & $31.0 \%$ \\
\hline & Middle School & 16 & $16.0 \%$ & 22 & $22.0 \%$ \\
\hline & High School & 41 & $41.0 \%$ & 28 & $28.0 \%$ \\
\hline & University & 39 & $39.0 \%$ & 19 & $19.0 \%$ \\
\hline \multirow{2}{*}{ Working Status } & Employed & 21 & $21.0 \%$ & 18 & $18.0 \%$ \\
\hline & Unemployed & 79 & $79.0 \%$ & 82 & $82.0 \%$ \\
\hline \multirow{4}{*}{ Spouse's Educational Status } & Elementary School & 10 & $10.0 \%$ & 22 & $22.0 \%$ \\
\hline & Middle School & 17 & $17.0 \%$ & 26 & $26.0 \%$ \\
\hline & High School & 31 & $31.0 \%$ & 36 & $36.0 \%$ \\
\hline & University & 42 & $42.0 \%$ & 16 & $16.0 \%$ \\
\hline \multirow{4}{*}{ Spouse's Occupation } & Unemployed & 5 & $5.0 \%$ & 1 & $1.0 \%$ \\
\hline & Civil servant & 31 & $31.0 \%$ & 14 & $14.0 \%$ \\
\hline & Worker & 33 & $33.0 \%$ & 35 & $35.0 \%$ \\
\hline & Self-employed & 31 & $31.0 \%$ & 50 & $50.0 \%$ \\
\hline \multirow{2}{*}{ Social Security } & Yes & 98 & $98.0 \%$ & 97 & $97.0 \%$ \\
\hline & No & 2 & $2.0 \%$ & 3 & $3.0 \%$ \\
\hline \multirow{4}{*}{ Perceived Monthly Income Level } & Low & 7 & $7.0 \%$ & 1 & $1.0 \%$ \\
\hline & Average & 93 & $93.0 \%$ & 81 & $81.0 \%$ \\
\hline & Poor & 0 & $0.0 \%$ & 4 & $4.0 \%$ \\
\hline & Good & 0 & $0.0 \%$ & 14 & $14.0 \%$ \\
\hline \multirow{2}{*}{ Family Type } & Nuclear & 82 & $82.0 \%$ & 80 & $80.0 \%$ \\
\hline & Extended & 18 & $18.0 \%$ & 20 & $20.0 \%$ \\
\hline \multirow{3}{*}{ Type of Home } & Squatter's home & 0 & $0.0 \%$ & 2 & $2.0 \%$ \\
\hline & Apartment & 93 & $93.0 \%$ & 78 & $78.0 \%$ \\
\hline & Villa & 7 & $7.0 \%$ & 20 & $20.0 \%$ \\
\hline
\end{tabular}

Table 2. Distribution of State/Trait Anxiety Inventory (STAI), Beck Anxiety Inventory (BAI) mean scores by the women's parity status during pregnancy

\begin{tabular}{lcccc}
\hline Characteristics & $\mathbf{n}$ & State Anxiety & Trait Anxietey & Depression \\
\hline Parity & & Mean \pm SD & Mean \pm SD & Mean \pm SD \\
\cline { 3 - 5 } Primiparae & 100 & $47.090 \pm 6.571$ & $47.090 \pm 6.571$ & $9.070 \pm 5.443$ \\
Multiparae & 100 & $41.270 \pm 4.925$ & $44.890 \pm 5.884$ & $11.830 \pm 7.068$ \\
$\mathrm{t}=$ & & 7.087 & 3.605 & -3.094 \\
$\mathrm{p}=$ & & $\mathbf{0 . 0 0 0}$ & $\mathbf{0 . 0 0 0}$ & $\mathbf{0 . 0 0 2}$
\end{tabular}

Source: Authors 


\begin{tabular}{|c|c|c|c|c|}
\hline Characteristics & $\mathbf{N}$ & EPDS & State Anxiety & Trait Anxiety \\
\hline Parity & & Mean \pm SD & Mean \pm SD & Mean \pm SD \\
\hline Primiparae & 100 & $4.520 \pm 5.068$ & $45.160 \pm 6.544$ & $45.560 \pm 7.119$ \\
\hline Multiparae & 100 & $5.950 \pm 5.845$ & $40.490 \pm 3.886$ & $41.630 \pm 4.775$ \\
\hline$t=$ & & -1.848 & 6.136 & 4.585 \\
\hline $\mathrm{p}=$ & & 0.066 & 0.000 & 0.000 \\
\hline
\end{tabular}

\section{Discussion}

Although pregnancy is considered a time in which positive emotions are felt, it may also be a period that brings with it serious psychological and emotional changes in a woman such as anxiety and depression. When we reviewed the state and trait anxiety levels of the pregnant primiparae and multiparae in our study, we discovered that the state anxiety of pregnant primiparae $(47.1 \%$, as opposed to $41.3 \%$ in multiparae) and their trait anxiety (48.8\%, as opposed to $44.9 \%$ in multiparae) placed them in the "highly anxious" category. It was thus seen that primiparae had a higher level of state and trait anxiety during pregnancy than their multiparae counterparts (Table 2). In the limited number of studies on the subject in the literature, it can be seen that anxiety rates reported in Turkey support our own findings. One researcher has reported a state anxiety rate of $37.4 \%$ and a trait anxiety rate of $44.4 \%$ (Koçak, 2014) for pregnant women while another has set forth a rate of $47.1 \%$ for state anxiety and of $90.4 \%$ for trait anxiety (Virit et al., 2008). In a study in which the researchers explored anxiety levels, Kaplan et al. (2007) found high rates of 58.0\% for state anxiety among pregnant primiparae and of $51.4 \%$ among multiparae (Kaplan et al., 2007). An international study has also revealed that the state anxiety rate among pregnant women is $59.5 \%$ while the trait anxiety rate is $45.3 \%$, demonstrating that pregnant women experience "high anxiety" in this period (Faisal-Cury \& Rossi Menezes, 2007). It is reported in studies that support the results of our own research that primiparae display higher state and trait anxiety scores compared to multiparae during pregnancy (Koçak, 2014; Akbaş et al., 2008).

When we looked at the period of pregnancy in terms of depression, we found a depression rate of $9.07 \%$ among primiparae, which was lower than the depression rate of $11.83 \%$ in multiparae, and the difference was significant $(\mathrm{p}<0.05)$. In other studies, researchers have similarly reported a depression rate of $12.0 \%$ among pregnant women (Cebeci et al., 2002) and varying rates of 8.2\%, 10.0\% and $2.0 \%$ during the first, second and third trimesters, respectively (Chen et al., 2004). In another systematic review, it was found that while the depression rate was $7.4 \%$ in the first trimester, the rate was $12.8 \%$ and $12 \%$ in the second and third trimesters, respectively (Bennett et al., 2004). We can therefore say that because they are experiencing pregnancy for the first time and due to their unfamiliarity with the effects and circumstances of being pregnant, primiparae tend to have increased anxiety and depression levels and are adversely affected psychologically.

In examining the state and trait anxiety status of primiparae and multiparae in the second month postpartum, we found that primiparae showed a slight decline in their state and trait anxiety levels compared to the period of their pregnancy but that they were still in the "high anxiety" category with a rate of $45.2 \%$ in state anxiety and $45.6 \%$ in trait anxiety levels. Multiparae on the other hand could be classified as having "slight anxiety," displaying a rate of $40.5 \%$ on the state anxiety and of $41.6 \%$ on the trait anxiety scale. It was thus seen that primiparae also had a higher level of state and trait anxiety during the postpartum period compared to their multiparae counterparts (Table 3). In a study in which the researchers explored state anxiety levels, Kaplan et al. (2007) found high rates of $41.9 \%$ among primipara mothers and $41.0 \%$ among multiparae (Kaplan et al., 2007). The results of a study by Y1ld1z and Akbayrak (2014) supported the outcome of the present study in that the researchers found that primiparae in the postpartum period experienced levels of trait anxiety that were $44.8 \%$ in the study group and $39.8 \%$ in the control group. State anxiety levels in the first three months sharply declined in the study group from $40.1 \%$ on Day 7 to $30.0 \%$ in the third month, while in the control group, there 
was no significant change from the rate of $35.6 \%$ on Day 7 to $35.3 \%$ in the third month (Y1ldiz \& Akbayrak, 2014). In another study, state anxiety among women in the postpartum period was reported as $40.0 \%$ while trait anxiety was found to be $42.9 \%$ (Erdem et al., 2010). The data show that the state and trait anxiety existing in the period of pregnancy that cannot be relieved with the needed support carries over into the postpartum period and manifests itself at a higher level in primiparae compared to multiparae.

The Edinburgh Postpartum Depression Scale (EPDS) indicated in our study that postpartum depression in primiparae was at a rate of $4.5 \%$ and at $5.9 \%$ in multiparae, but that in both groups, there was a $50 \%$ decrease compared to the period of pregnancy, placing the women in the no-risk group (Table 3). Although both the primiparae and multiparae in our study were in the no-risk group, it was seen that as in the period of pregnancy, the multiparae displayed a higher postpartum depression rate than the primiparae (Table 2). Similar to the results of our study, other studies carried out with EPDS have revealed postpartum depression rates of 8.7\% (Aksoy et al., 2016) and 7.6\% (Özkan et al., 2014). To summarize, it can be said that depression related to childbirth diminishes with delivery but at the same time, depending upon the number of children multiparae have, increasing burdens of responsibility may cause multiparae to display higher rates of depression compared to primipara mothers.

\section{Conclusion}

In the light of our study results and those reported in the literature, it was seen that primiparae have higher levels of state and trait anxiety both in pregnancy and in the postpartum period compared to multiparae but, to the contrary, multiparae display higher levels of depression compared to primiparae. It can be recommended therefore that healthcare personnel display more awareness and take on more responsibility when providing care and counseling services in order to closely monitor and identify risks related to the psychological state of wellness of women during pregnancy and in the postpartum period.

\section{References}

Akdeniz, F., \& Gönü,1 A.S.(2004). Kadınlarda üreme olayları ile depresyon ilişkisi. Klin Psikiyatr Derg. Ek 2:70-4

Beck, C.T.(2001). Predictors of postpartum depression, an update. Nursing Research. 50(5):275.

Erkaya, R., Gürsoy, A.A., \& Güler, H. (2012). Annelerin Anne Sütünü Artırmaya Yönelik Aldıkları Besinler. Gümüşhane Üniversitesi Sağlık Bilimleri Dergisi, 4(3): 373 - 387.

Karaçam, Z., \& Ançel, G. (2007). Depression, anxiety and influencing factors in pregnancy: a study in a Turkish population. Midwifery Oct 10; [Epub ahead of print]

Gölbaşi, Z., Kelleci, M., Kisacik, G., \& Cetin, A.(2010). Prevalence and correlates of depression in pregnancy among Turkish women. Matern. Child Health J. 14, 485-491.

Faisal-Cury, A., \& Rossi Menezes, P.(2007). Prevalence of anxiety and depression during pregnancy in a private setting sample. Arch Women's Ment Health;10:25-32

Marcus, S.M., Flynn, H.A., Blow, F.C., \& Barry, K.L. (2003). Depressive symptoms among pregnant women screened in obstetrics settings. J. Women's Health (Larchmt) 12, 373-380.

Da Costa, D., Larouche, J., Dritsa, M., \& Brender, W.(2000). Psychosocial correlates of prepartum and postpartum depressed mood. J Affect Disord 59:31-40.

Kurki, T., Hiilesmaa, V., Raitasalo, R., Mattila, H., \& Ylikorkala, O. (2000). Depression and anxiety in early pregnancy and risk for preeclampsia. Obstet Gynecol 95:487-90.

Kuğu, N., \& Akyüz, G. (2001). Gebelikte Ruhsal Durum. Cumhuriyet Üniversitesi Tıp Fakültesi Dergisi. 23:61-4.

Lee, A.M., Lam, S.K., Sze Mun Lau, S.M., Chong, C.S., Chui, H.W., \& Fong, D.Y.(2007). Prevalence, course, and risk factors for antenatal anxiety and depression. Obstet Gynecol 110: 1102-12.

Orr, S.T., James, S.A., \& Blackmore, P.C.(2002). Maternal prenatal depressive symptoms and spontaneous preterm births among African-American women in Baltimore, Maryland. Am J Epidemiol 156: 797-802.

Hoffman, S., \& Hatch, M.C.(2000). Depressive symptomatology during pregnancy: evidence for an association with decreased fetal growth in pregnancies of lower social class women. Health Psychol 19: 535-43.

Hobel, C. J. (1999). Maternal plasma corticotropin-releasing hormone associated with stress at 20 weeks gestation in pregnancies ending in preterm delivery. Am J Obstet Gynecol 180: 257-63.

Bloch, M., Daly, R.C., \& Rubinow, D.R.(2003). Endocrine factors in the etiology of postpartum depression. Compr Psychiatry. 44:234-246.

Bloch, M., Rotenberg, N., Koren, D., \& Klein, E. (2006). Risk Factors For Early Postpartum Depressive Symptoms. Gen Hosp Psychiatry; 28:3-8. 
Robertson, E., Grace, S., Wallington, T., \& Stewart, D.E. (2004). Antenatal risk factors for postpartum depression: a synthesis of recent literature. Gen. Hosp. Psychiat; 26: 289-295.

Woolhouse, H., Gartland, D., Perlen, S., Donath, S., \& Brown, S.J. (2014). Physical health after childbirth and maternal depression in the first 12 months postpartum: results of an Australian nulliparous pregnancy cohort study. Midwifery; 30 (3) : 378-384.

Stewart, D.E., Gagnon, A., Saucier, J.F., Wahoush, O., \& Dougherty, G.(2008). Postpartum depression symptoms in newcomers. Can J Psychiatry. 53(2):121-124.

Durukan, E., İlhan, M.N., Bumin, M.A., \& Aycan, S. (2011). 2 hafta-18 aylık bebeği olan annelerde postpartum depresyon sıklığ ve yaşam kalitesi. Balkan Med J, 28:385-93.

Sünter, A.T., Güz, H., Canbaz, S., \& Dündar, C. (2006). Samsun il merkezinde doğum sonrası depresyonu prevalans1 ve risk faktörleri. Türk Jinekoloji ve Obstetrik Derneği Dergisi; 3 (1) :26-31.

Inand1, T., Buğdayc1, R., Dündar, P., Sümer, H., \& Şaşmaz, T. (2005). Risk factors for depression in the first postnatal year. A Turkish study. Soc Psychiatry Psychiatr Epidemiol 40:725-30.

Nur, N., Çetinkaya, S., Bakır, D.A., \& Demirel, Y.(2004) Prevalence of Postnatal Depression and Risk Factors in Women in Sivas City. Cumhuriyet Tip Derg 26:55-9.

Yıldırım, A., Hacıhasanoğlu, R., \& Karakurt, P.(2011) Postpartum depresyon ile sosyal destek arasındaki ilişki ve etkileyen faktörler. Uluslararası İnsan Bilimleri Dergisi. 8(1): 31-46.

Öner, N., \& Le Compte, A. (1983). Süreksiz Durumluk/Sürekli Kaygı Envanteri El Kitabı, 1. Baskı, Boğaziçi Üniversitesi Yayınları, İstanbul, ss: 1-26.

Beck, A.T., Epstein, N., Brown, G., \& Steer, R.A.(1988). An inventory forme asuring clinical anxiety: Psychometric properties. J Consult Clin Psychol 56:893-7.

Ulusoy, M., Şahin, N., \& Erkman, H.(1998). Turkish Version of The Beck Anxiety Inventory: Psychometric properties. J Cognitive Psychotherapy: Int Quaterly 12:28-35.

Engindeniz, A.N., Küey, L., \& Kültür, S. (1997). Edinburgh Doğum Sonrası Depresyon Ölçeği Türkçe formu geçerlilik ve güvenilirlik çalışması. Bahar Sempozyumları 1 Kitabı. Ankara: Psikiyatri Derneği Yayınları s.51-2.

Karaçam, Z., \& Kitiş, Y.(2007). Doğum Sonrası Depresyon Tarama Ölçeği: Türkçede Geçerlik ve Güvenirliği, Türk Psikiyatri Dergisi (18):3-9.

Koçak, V.(2014). Prenatal Tarama Testi İçin Başvuran Gebelerde Kaygı Düzeyi Ve İlişkili Faktörler.Yüksek Lisans Tezi.Konya.

Vırıt, O., Akbaş, E., Savaş, H.A., Sertbaş, G., \& Kandemir, H. (2008). Gebelikte Depresyon ve Kaygı Düzeylerinin Sosyal Destek ile ilişkisi. Nöropsikiyatri Arşivi. 45:9-13.

Kaplan, S., Bahar, A., \& Sertbaş, G.(2007). Gebelerde Doğum Öncesi Ve Doğum Sonrası Dönemlerde Durumluk Kayg1 Düzeylerinin İncelenmesi. Atatürk Üniversitesi Hemşirelik Yüksekokulu Dergisi, 10: 1.

Akbaş, E., Vırıt, O., Kalenderoğlu, A., Savaş, H.A., \& Sertbaş, G. (2008). Gebelikte sosyodemografik değişkenlerin kaygı ve depresyon düzeyleriyle ilişkisi. Nöropsikiyatri Arşivi 45(3):85-91.

Cebeci, S.A., Aydemir, C., \& Goka, E. (2002). Puerperal donemde depresyon semptom prevalansı: obstetrik risk faktorleri, kayg1 duzeyi ve sosyaldestek ile iliskisi. Kriz Derg 10:11-8.

Chen, H., Chan, Y.H., Tan, K.H., \& Lee, T.(2004). Depressive symptomatology in pregnancy - a Singaporean perspective. Soc Psychiatry Psychiatr Epidemiol 39:975-9.

Bennett, H.A., Einarson, A., Taddio, A., Koren, G., \& Einarson T.R. (2004). Prevalence of depression during pregnancy: systematic review. Obstetrics and Gynecology. 103:698-709.

Yıldız, D., \& Akbayrak, N.(2014). Doğum sonrası primipar annelere verilen eğitim ve danışmanlık hizmetlerinin bebek bakımı, kaygı düzeyleri ve annelik rolüne etkisi. Gülhane Tıp Dergisi. 56(1): 36-41.

Erdem, Ö., Bucaktepe, G.E., Özen, Ş., \& Kara, İ.H.(2010). Prepartum ve postpartum dönemde annelerin duygu durumlarının incelenmesi. Düzce Tip Dergisi 12(3): 24-31.

Aksoy, Y.E., Ünal, F., İçcke, G., Çil, G., Oruç, K., Yılmaz, T., Yıldırım, Ş., \& Yılmaz S. (2016).Postpartum depresyonun emzirme üzerine etkisi. GÜSBD. 5(3): 90-6.

Özkan, H., Üst, Z.D., Gündoğdu, G., Çapık, A., \& Şahin, S.A. (2014). Erken postpartum dönemde emzirme ve depresyon arasındaki ilişki. Şişli Etfal Hast Tip Bul 125-32. 